DOI https://doi.org/10.30525/978-9934-26-182-4-46

\title{
CLINICAL AND EPIDEMIOLOGICAL SPECIFICITY OF THE OMICRON VARIANT AND THE PROSPECTS FOR ITS SPREAD
}

\author{
Korolenko V. V. \\ assistant professor, \\ Bogomolets National Medical University \\ Kyiv, Ukraine
}

\section{Introduction.}

The first report of B.1.1.529 variant WHO was received from South Africa on November 24, 2021. And the number of infections has increased sharply, which coincided with the discovery of this option. The first known confirmed B.1.1.529 infection was from a sample collected on November 9, 2021 [1].

On the advice of the WHO Technical Advisory Group on Virus Evolution, on 26 November 2021, WHO identified Option Omicron as a matter of concern [2].

B.1.1.529 is a very divergent variant with a huge number of mutations, including 26-32 mutations in the spike protein, identified with which may be associated with the humoral immune escape potential, as well as the most significant transmissibility. On December 22, 2021, the Omicron variant was found in 110 countries in all six WHO regions. [3]

In Ukraine, on December 18, 2021, according to the results of full-genome sequencing, the first case of coronavirus infection with Omicron (B.1.1.529like) was detected. A person infected with this variant of the coronavirus has returned from the United Arab Emirates [4].

\section{Methods.}

Comparison, analysis and generalization of literature data thorough the bibliosemantic method is used.

\section{Results.}

Preliminary information from South Africa has shown that patients do not have any unusual symptoms associated with Omicron infection, and even, as with other coronavirus variants, some patients have no symptoms. [5]

However, currently early data suggest that Omicron infection may be less than previous variants; however, reliable data on clinical severity remain limited. Even if the proportion of infections with severe consequences is lower than in previous versions, given the possible increase in the number of 
infections, the absolute number of people with severe consequences can be significant. [6]

Dissemination of findings from observations based on known mutations, which should be interpreted with caution, suggests that B.1.1.529 may spread faster and escape antibodies more easily than previous versions, thereby increasing re-infection and mild breakthrough cases infections. According to previous opinion polls, vaccinated people have a much lower risk of serious illness caused by infection B.1.1.529. [7]

Simulated by the Centers for Disease Control and Prevention (CDC), by synthesizing models of epidemic trajectory scenarios with faster relative growth rates (Omicron compared to Delta) in the United States, indicate that in early January 2022 in the United States may begin a major outbreak of infections and that the peak daily number of new infections may exceed previous peaks. With low immune evasion, the surge may be lower and occur in April 2022. [6]

Given the estimates of the spread of Omicron, including in European countries, in Ukraine it may affect the epidemic dynamics in early January 2022 [8].

\section{Conclusions.}

As WHO identified B.1.1.529 as a concern, epidemiological surveillance needs to be exacerbated and active genomic sequencing of samples activated.

Monitoring and regular analysis of available data on SARS-CoV-2 genetic sequences is very important to support response and control measures. [9]

\section{References:}

1. Classification of Omicron (B.1.1.529): SARS-CoV-2 Variant of Concern, 26 November 2021. WHO|World Health Organization. URL: https://www.who.int/news/item/26-11-2021-classification-of-omicron(b.1.1.529)-sars-cov-2-variant-of-concern

2. Update on Omicron, 28 November 2021. WHO|World Health Organization. URL: https://www.who.int/news/item/28-11-2021-update-onomicron

3. Enhancing readiness for Omicron (B.1.1.529): Technical brief and priority actions for Member States, 23 December 2021. World Health Organization . URL: file:///C:/Users/user/Downloads/2021-12-23-Globaltechnical-brief-and-priority-action-on-Omicron\%20(1).pdf

4. В Україні виявили штам «Омікрон», 18 грудня 2021. Міністерство охорони здоров'я України. URL: https://moz.gov.ua/article/news/v-ukrainivijavili-shtam-omikron 
5. Science Brief: Omicron (B.1.1.529) Variant, Dec. 2, 2021. Centers for Disease Control and Prevention. URL: https://www.cdc.gov/coronavirus/2019ncov/science/science-briefs/scientific-brief-omicron-variant.html

6. Potential Rapid Increase of Omicron Variant Infections in the United States, Dec. 20, 2021 Centers for Disease Control and Prevention. URL: https://www.cdc.gov/coronavirus/2019-ncov/science/forecasting/mathematical-modeling-outbreak.html\#ref04

7. Karim S. S A., Karim Q.A., Omicron SARS-CoV-2 variant: a new chapter in the COVID-19 pandemic. The Lancet Infectious Diseases. December 03, 2021. DOI: https://doi.org/10.1016/S0140-6736(21)02758-6

8. Прогноз розвитку епідемії COVID-19 в Україні на 22 грудня 2021 року -4 січня 2022 року («Прогноз РГ-58»). Національна академі наук України. URL: https://www.nas.gov.ua/UA/Messages/Pages/View.aspx? MessageID $=8551$

9. Kiianytsia V.V., NEW VARIANTS OF THE SARS-COV-2 VIRUS AND THEIR IMPACT ON THE EPIDEMIC PROCESS SCIENTIFIC PROGRESS OF MEDICINE AND PHARMACY OF THE EU COUNTRIES. (Czestochowa, Republic of Poland, April 23-24, 2021). Czestochowa: Polonia University in Czestochowa, 2021. 192-196

DOI https://doi.org/10.30525/978-9934-26-182-4-47

\title{
THE ROLE OF HUMAN POTENTIAL AS A SOCIO-MEDICAL CATEGORY FOR THE DEVELOPMENT OF A POWERFUL STATE
}

\author{
Korolenko V. V. \\ $M D, D S c$, Deputy Head \\ State Service of Ukraine for Medicines and Drugs Control \\ Kyiv, Ukraine
}

Human potential is a set of opportunities of society, the state and individuals in the use of human resources and productive human traits (business, social, moral, spiritual) for any socially useful activity. In most theoretical approaches, it is considered mainly at the level of civilization and macroeconomic and is interpreted as the main driving force of economic growth [1].

Structurally, human potential includes several components (socioeconomic, socio-cultural, activity and socio-demographic), of which sociodemographic potential has directly the socio-medical nature. It covers 